\title{
A DESCRIPTIVE STUDY ON PATIENTS OF CARCINOMA LARYNX ATTENDING TERTIARY CARE CENTRES IN HYDERABAD, TELANGANA
}

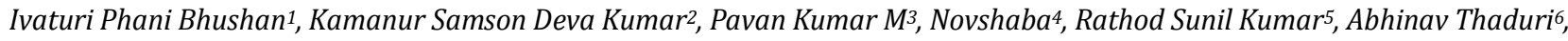 \\ Dipin Kumar. V7, Chandra Shekhar Annam ${ }^{8}$
}

\author{
${ }^{1}$ Senior Resident, Department of Otorhinolaryngology, Gandhi Medical College. \\ ${ }^{2}$ Assistant Professor, Department of Otorhinolaryngology, Gandhi Medical College. \\ ${ }^{3}$ Assistant Professor, Department of Otorhinolaryngology, Shadan Institute of Medical Sciences. \\ ${ }^{4}$ Postgraduate Student, Department of Otorhinolaryngology, Gandhi Medical College. \\ 5 Postgraduate Student, Department of Otorhinolaryngology, Gandhi Medical College. \\ ${ }^{6}$ Postgraduate Student, Department of Otorhinolaryngology, Gandhi Medical College. \\ ${ }^{7}$ Postgraduate Student, Department of Otorhinolaryngology, Gandhi Medical College. \\ 8Postgraduate Student, Department of Otorhinolaryngology, Gandhi Medical College.
}

ABSTRACT
BACKGROUND
Laryngeal cancer is the eleventh most common cancer in men worldwide, but is rela
constitutes $2.63 \%$ of all body cancers in India. Tobacco smoking and alcohol are the
presenting complaints of laryngeal cancer are hoarseness, dysphagia and referred
neck.
Objectives-
1. To describe sociodemographic factors among patients with carcinoma larynx.
2. To assess the spectrum of clinical features in patients with laryngeal carcinoma.
3. To determine the histopathological pattern in carcinoma larynx patients.

\section{MATERIALS AND METHODS}

A descriptive study was undertaken in ENT Department of Gandhi Hospital and MNJ Cancer Institute, which are tertiary care centres in Hyderabad, Telangana for a period of 2 years (November 2014 -October 2016). Fifty patients who were clinically diagnosed as carcinoma larynx were included in the study. Ethical clearance was obtained from institutional ethics committee. Informed consent was obtained from the patients before including them in the study.

\section{RESULTS}

The maximum incidence of carcinoma larynx in this study was found in the age group of 41-60 years (52\%) followed by the 6180 years age group (42\%). Around $94 \%$ of Cases were male. Almost $96 \%$ of patients belonged to low socioeconomic status. Chief complaint noted in this study was change in voice $-48 \%$. Alcohol consumption and beedi smoking were found to be the contributing factors in the occurrence of carcinoma larynx.

\section{CONCLUSION}

Around $98 \%$ of cases showed squamous cell carcinoma on histopathological examination. The most common site of carcinoma larynx was glottis (54\%) followed by supraglottis region (44\%).

\section{KEYWORDS}

Carcinoma Larynx, Histopathological Pattern, Sociodemographic Factors, Gandhi Hospital and MNJ Cancer Institute. HOW TO CITE THIS ARTICLE: Bhushan IP, Kumar KSD, Kumar PM, et al. A descriptive study on patients of carcinoma larynx attending tertiary care centres in Hyderabad, Telangana. J. Evolution Med. Dent. Sci. 2018;7(03):302-305, DOI: $10.14260 /$ jemds/2018/67

\section{BACKGROUND}

Laryngeal cancer is the eleventh most common cancer among men worldwide, ${ }^{1}$ but is relatively uncommon in women. Cancer larynx constitutes $2.63 \%$ of all body cancers in India. It is ten times more common in males $(4.79 \%)$ than in females $(0.47 \%)$. Its incidence is 3.29 new cases in males and 0.42 new cases in females per 100,000 population.

'Financial or Other Competing Interest': None.

Submission 27-11-2017, Peer Review 28-12-2017,

Acceptance 03-01-2018, Published 13-01-2018.

Corresponding Author:

Dr. Kamanur Samson Deva Kumar,

310, RV Padmalaxmi Apartment,

Door No 6-1-171, Padmarao Nagar, Secunderabad

E-mail: samsonkamanur@yahoo.com

DOI: $10.14260 /$ jemds/2018/67

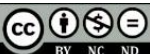

Disease is mostly seen in the age group of 40-70 years but younger people in thirties may occasionally be affected. ${ }^{2}$

Within the larynx, tumours may arise from the vocal cords (glottic), superior to the vocal cords (supraglottic), or from below the vocal cords (subglottic). ${ }^{3}$

About $60 \%$ of larynx cancers start in the glottis, 35\% develop in the supraglottic region and the remaining $5 \%$ occur in the subglottis. ${ }^{4}$ Throat pain, dysphagia and referred pain in the ear or mass of lymph nodes in the neck may be the presenting features. Hoarseness of voice is an early sign for Glottic Cancer because lesions of cord affect its vibratory capacity.

Tobacco smoking and alcohol are the main risk factors for laryngeal cancer, and their effects are synergistic. There is a strong association between laryngeal cancer and cigarette smoking. Smoking is the main risk factor for glottic cancers, 
whereas alcohol appears to be the bigger risk factor for supraglottic tumours. The combined use of tobacco and alcohol increases the risk of laryngeal cancer by $50 \%$ over the estimated risk. $^{3}$

About $90-95 \%$ of laryngeal malignancies are squamous cell carcinoma with various grades of differentiation. Verrucous carcinomas comprise $1 \%$ to $2 \%$ of all laryngeal cancers. One tenth of malignant tumours are represented by adenocarcinoma, salivary gland carcinoma, sarcoma, and malignant lymphoma. ${ }^{1}$

\section{Aims and Objectives}

- To describe sociodemographic factors among patients with carcinoma larynx.

- To assess the spectrum of clinical features in patients with laryngeal carcinoma.

- To determine the histopathological pattern in carcinoma larynx.

\section{MATERIALS AND METHODS \\ Study Design \\ Descriptive study.}

\section{Study Area}

Ear, Nose and Throat Department of Gandhi Medical College, Secunderabad and MNJ Cancer Institute, Hyderabad.

\section{Study Duration}

2 years (November 2014 - October 2016).

Sample Size- A convenient sample of 50 patients was taken. Study population: All patients of carcinoma larynx were taken.

\section{Inclusion Criteria}

All proven cases of Primary invasive laryngeal carcinoma, who have not undergone any treatment.

\section{Exclusion Criteria}

Patients with Carcinomatous growths extending into Larynx from surrounding tissues, Carcinoma in situ lesions, Patients with Carcinoma Larynx who underwent any sort of treatment (Surgery, Radiotherapy, Chemotherapy) and patients with benign lesions were excluded from the study.

\section{Study Tools}

A semi-structured questionnaire was used to collect sociodemographic details, data on history of exposure and clinical presentation. Thorough Head \& Neck Examination was conducted. Indirect Laryngoscopy and Direct Laryngoscopy were performed on all study subjects. Biopsy was taken from Laryngeal growth and was sent to the Department of Pathology for histopathological examination. CT Scan Neck was also done wherever it was essentially required.

\section{Data Analysis}

Data was analysed using MS excel and Epi info. Descriptive statistics in the form of percentages and proportions are mentioned.

Ethical considerations: Ethical clearance from institutional ethics committee was obtained prior to start of the study. Informed consent was taken from all the participants before administering questionnaire.
RESULTS

\begin{tabular}{|c|c|c|}
\hline Age (Years) & Number & $\%$ \\
\hline $21-40$ & 3 & 6 \\
\hline $41-60$ & 26 & 52 \\
\hline $61-80$ & 21 & 42 \\
\hline Gender & Number & $\%$ \\
\hline Male & 47 & 94 \\
\hline Female & 3 & 6 \\
\hline Religion & Number & $\%$ \\
\hline Hindu & 42 & 84 \\
\hline Muslim & 5 & 10 \\
\hline Christian & 3 & 6 \\
\hline SES & Number & $\%$ \\
\hline$\overline{B P L}$ & 48 & 96 \\
\hline APL & 2 & 4 \\
\hline Region & Number & $\%$ \\
\hline Adilabad & 3 & 6 \\
\hline Hyderabad & 7 & 14 \\
\hline Karimnagar & 4 & 8 \\
\hline Khammam & 3 & 6 \\
\hline Mahboobnagar & 10 & 20 \\
\hline Medak & 5 & 10 \\
\hline Nalgonda & 8 & 16 \\
\hline Nizamabad & 2 & 4 \\
\hline Rangareddy & 4 & 8 \\
\hline Warangal & 4 & 8 \\
\hline Total & 50 & 100 \\
\hline
\end{tabular}

Among the study population, the mean age was 57.28 years. The maximum incidence of carcinoma larynx was among $41-60$ years (52\%) followed by the 61-80 years $(42 \%)$. The present study findings were similar to a study conducted by Maier $\mathrm{H}$, Tisch $\mathrm{M}$ et al, where the highest incidence of laryngeal cancer was found in the age group of 50-69 years of age.5,6 The mean age of study participants was also concurrent with a study conducted by Muhammad Rashidzia, Ghulam Murtaza, et al wherein the mean age was 57 years. ${ }^{7 T h e}$ male to female ratio in the occurrence of carcinoma larynx was $15.66: 1$. In the present study, $84 \%$ of cases were among patients belonging to Hindu religion and $10 \%$ of cases were Muslims. The study findings in relation to gender distribution were similar to a study conducted by Chevalier Jackson and Hayes Martin where male predominance was found. ${ }^{8}$ Majority (96\%) of study subjects were from below poverty line families, which was similar to a study conducted by J M El Wood J et al which found an association of increased risk of carcinoma larynx with low socioeconomic status. ${ }^{9}$

Majority of cases were from Mahboobnagar district (20\%), followed by Nalgonda (16\%). Around $14 \%$ of cases were reported from Hyderabad and 10\% cases were from Medak district of Telangana region.

\begin{tabular}{|c|c|c|}
\hline Occupation & Number & \% \\
\hline None & 4 & 8 \\
\hline Labourer & 14 & 28 \\
\hline Farmer & 20 & 40 \\
\hline Mechanic & 7 & 14 \\
\hline Rickshaw puller & 1 & 2 \\
\hline Pot worker & 1 & 2 \\
\hline Shop keeper & 6 & 12 \\
\hline Total & $\mathbf{5 0}$ & $\mathbf{1 0 0}$ \\
\hline Table 2. Distribution of Study Population According to \\
Occupation \\
\hline
\end{tabular}


In the present study, it was found that $40 \%$ of study subjects were farmers by occupation and $28 \%$ of them were labourers. Around $14 \%$ of study subjects were mechanics and $12 \%$ were shop keepers. This was similar to a study conducted by Zagraniski RT et al.10

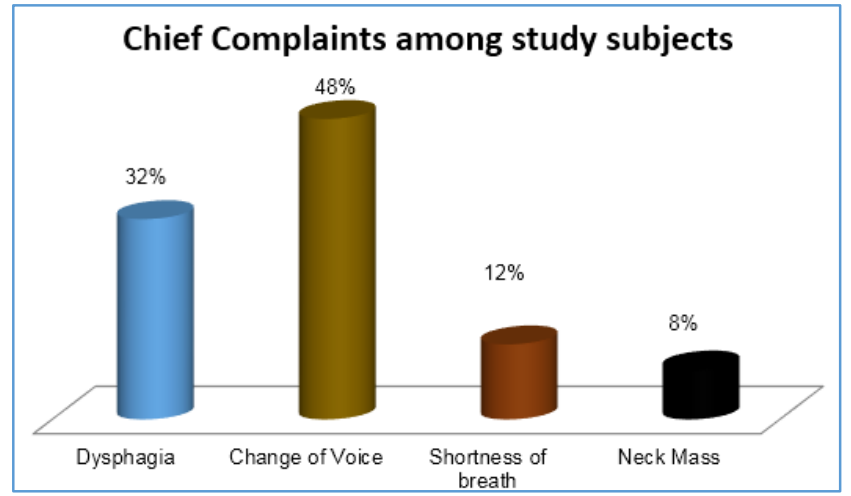

Figure 1. Distribution of Study Population According to Chief Complaints

In the present study, $48 \%$ of study subjects presented with change in voice, and $32 \%$ presented with dysphagia. Twelve percent presented with shortness of breath and around $8 \%$ of them presented with neck mass.

\begin{tabular}{|c|c|c|c|}
\hline $\begin{array}{c}\text { Location of } \\
\text { Tumour }\end{array}$ & Complaint & Number & $\%$ \\
\hline \multirow{5}{*}{ Supraglottic } & Dysphagia & 12 & 54.54 \\
\hline & Change of voice & 4 & 18.18 \\
\hline & Shortness of breath & 2 & 09.09 \\
\hline & Neck Mass & 4 & 18.18 \\
\hline & Total & 22 & 100 \\
\hline \multirow{4}{*}{ Glottic } & Dysphagia & 4 & 14.81 \\
\hline & Change of voice & 20 & 74.07 \\
\hline & Shortness of breath & 3 & 11.11 \\
\hline & Total & 27 & 100 \\
\hline \multirow{2}{*}{ Subglottic } & Shortness of breath & 1 & 100 \\
\hline & Total & $\mathbf{1}$ & 100 \\
\hline \multicolumn{4}{|c|}{$\begin{array}{l}\text { Table 3. Distribution of Study Population According to } \\
\text { Location of Tumour and Chief Complaint }\end{array}$} \\
\hline
\end{tabular}

\section{DISCUSSION}

In the present study, it was found that $54 \%$ of study subjects had glottis cancer, $44 \%$ had supraglottic cancer and $2 \%$ had subglottic cancer. Among the subjects with supraglottic cancer, dysphagia (54.54\%) was the commonest presentation. Among cases with glottic cancer, change in voice $(74.07 \%)$ was the commonest clinical presentation. Only one case of subglottic cancer was reported during study period and the presenting complaint was shortness of breath. These findings were consistent with a study by Shukla et $\mathrm{al}^{11}$ where change in voice $(75.41 \%)$ and dysphagia $(63.35 \%)$ were the common clinical presentations. Similar findings were found in a study by Yerma et al ${ }^{12}$ and Hanni Raitiola et al. 13

In this study, it was found that $54 \%$ of them had glottis cancer and $44 \%$ of cases had supraglottis cancer. These findings were different when compared to a study conducted by Purohit k et al, ${ }^{14}$ where supraglottis cancer (63\%) was the commonest site of presentation.

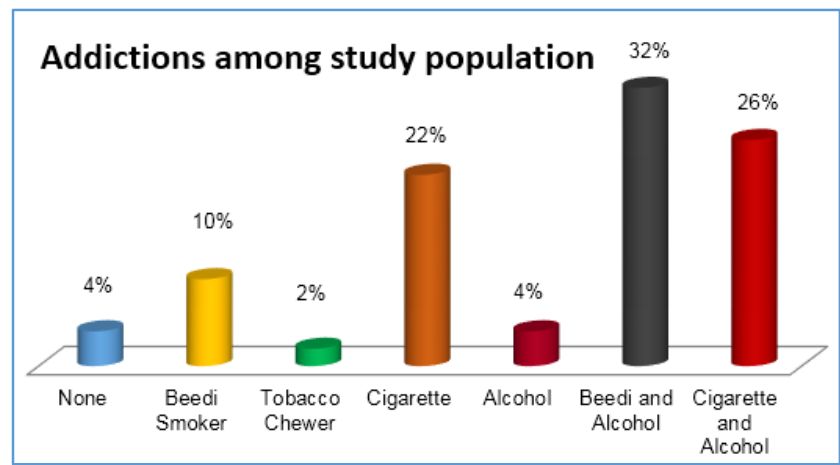

Figure 2. Distribution of Study Population According to Addictions

In the present study, $32 \%$ of the subjects were both chronic beedi smokers and Alcoholics and $26 \%$ of them were both chronic cigarette smokers and alcoholics. Around 22\% of cases were chronic cigarette smokers alone, $10 \%$ were Beedi smokers alone. These findings were concurrent to Maier $\mathrm{H}$ et al findings where tobacco and alcohol consumption increased the risk of head and neck cancer in a dose-dependent manner and acted as independent risk factors also. ${ }^{6}$

The most common histopathological pattern in this study was squamous cell carcinoma (98\%) followed by lymphoma (2\%) which was comparable to a study by Thakur et al. ${ }^{15}$

In the present study, $40 \%$ of cases had palpable neck nodes, while $60 \%$ of them did not have palpable lymph nodes. This finding was consistent with a study conducted by Hanni Raitola et al. ${ }^{13}$

\section{CONCLUSION}

In the present study, it was found that carcinoma larynx was common in older age group and among males. It was found that cigarette consumption alone or in combination with alcohol was related to occurrence of carcinoma larynx. The most common site of tumour was glottis, followed by supraglottic region. The most common clinical presentation was change in voice and dysphagia and the most common histopathological presentation was squamous cell carcinoma.

\section{REFERENCES}

[1] Gleeson MJ, Clarke RC. Scott-Brown's Otorhinolaryngology, Head and Neck Surgery. Vol 2. $7^{\text {th }}$ edn. London: Hodder Arnold 2008:2600-8.

[2] Dhingra PL. Diseases of ear, nose and throat. $6^{\text {th }}$ edn. Elsevier 2014:307-9.

[3] Watkinson J, Gilbert RW. Stell and Maran's Textbook of head and neck surgery and oncology. $5^{\text {th }}$ edn. Hodder Arnold 2012; p. 645.

[4] Watkinson J, Gilbert RW. Stell and Maran's Textbook of head and neck surgery and oncology. $5^{\text {th }}$ edn. Hodder Arnold 2012; p. 13.

[5] Maier H, Tisch M. Epidemiology of laryngeal cancer: results of the Heidelberg case-control study. Acta Otolaryngol Suppl (Stockh) 1997;527:160-4.

[6] Maier H, Gewelke U, Dietz A, et al. Risk factors of cancer of the larynx: results of the Heidelberg case control study. Otolaryngol Head Neck Surg 1992;107(4):577-82. 
[7] Zia MR, Murtaza G, Raza N, et al. Overview of clinical presentation of laryngeal malignancy. Biomedica 2005;21:1-4.

[8] Satyanarayana C. Cancer of the larynx and narrowfield laryngectomy. Indian J Otolaryngol 1953;5(2):4164.

[9] Elwood JM, Pearson JC, Skippen DH, et al. Alcohol, smoking, social and occupational factors in the aetiology of cancer of the oral cavity, pharynx and larynx. International Journal of Cancer 1984;34(5):603-12.

[10] Zagraniski RT, Kelsey JL, Walter SD. Occupational risk factors for laryngeal carcinoma: Connecticut, 19751980. American Journal of Epidemiology 1986;124(1):67-76.
[11] Shukla GK, Sharma H, Mishra SC, et al. Nodal patterns in carcinoma larynx and hypopharynx. IJO\& HNS 1995;47(3):190-5.

[12] Yerma A, Mehta S, Panda NK, et al. Presentation of carcinoma larynx and laryngopharynx - an analysis of 840 cases. Indian J Otolaryngol 1990;42(2):50-3.

[13] Raitiola H, Pukander J, Laippala P. Glottic and supraglottic laryngeal carcinoma: differences in epidemiology, clinical characteristics and prognosis. Acta Oto-Laryngologica 1999;119(7):847-51.

[14] Purohit K, Bist SS, Agarwal V, et al. A study of clinicopathological parameters in patients of carcinoma larynx. J Evolution Med Dent Sci 2016;5(34):1876-80.

[15] Thakur S, Chaturvedi VN, Singh AKK, et al. Pattern of ear, nose, pharynx, larynx and oesophagus (enplo) cancers in a rural based hospital. Indian J Otolaryngol Head Neck Surg 2001;53(2):93-9. 